Leo J. Thomsen MD, Søren Riisager MD, Kjeld A. Jensen MD, Lars Bünemann MD,

\title{
Cerebral blood flow and metabolism during hypotension induced with sodium nitro- prusside and captopril
}

Cerebral blood flow and metabolism have been studied in 11 patients during general anaesthesia and hypotension induced with sodium nitroprusside in combination with captopril. Cerebral blood flow was measured, using a Novo Cerebrograph model 10A, after injection of 133 xenon into an arm vein. Arterial and venous blood samples were drawn to calculate cerebral metabolism. Captopril $1 \mathrm{mg} \cdot \mathrm{kg}^{-1}$ orally was given one hour before induction of anaesthesia. The sodium nitroprusside doses ranged between 0.16 and $3.23 \mu \mathrm{g} \cdot \mathrm{kg}^{-1} \cdot \mathrm{min}^{-1}$. Mean arterial pressure was reduced 26 per cent $1046 \mathrm{mmHg}$ during hypotension. It is concluded that for the group as a whole there were no changes in $\mathrm{CBF}$ and $C M R \mathrm{O}_{2}$ during hypotension. In one patient, however, critical low CBF measurements were recorded during and after hypotension. This indicates the need for further studies concerning the cerebral haemodynamic consequences of captopril and SNP-induced hypotension.

Induced hypotension during surgical procedures is an established method to minimize intraoperative bleeding. In otorhinolaryngological surgery this may improve visibility for the surgeon, which means less tissue damage and hence better wound healing. Hypoperfusion of the brain is a potential risk when using hypotension. Thus the advantage of a better operative result must be weighed against the risk of cerebral ischaemia. ${ }^{1}$ Sodium nitroprusside (SNP) is a vasodilator acting directly on the smooth muscle cells of the blood vessels, producing hypotension.

\section{Key words}

ANAESTHETIC TECHNIQUES: hypotensive; BRAIN: bloodflow, metabolism, oxygen consumption; HYPOTENSION, INDUCED: captopril, sodium nitroprusside; SURGERY: otolaryngologic.

From the Department of Anaesthesia, Hjørring Municipal Hospital, Hjørring, Denmark.

Address correspondence to: Dr. L. J. Thomsen, Park Alle 21, DK-9800 Hjørring, Denmark.
The sympatho-adrenal and renin-angiotensin-aldosterone systems are thereby activated. This may increase the requirement for SNP and, because cyanide is a breakdown product of SNP, increase the risk of cyanide poisoning. Human studies ${ }^{2-4}$ have shown that a combination of SNP and captopril, an inhibitor af angiotensin converting enzyme, allows the use of smaller doses of SNP. Our study was designed to investigate the effects of induced hypotension produced by a combination of SNP and captopril on cerebral blood flow and metabolism.

\section{Methods}

The study was approved by the local ethics committee and patients gave informed consent according to the Declaration of Helsinki. Eleven patients (nine male, two female) with a mean age of 29 years $(20-44)$ were studied while undergoing corrective operations for deviation of the nasal septum. ${ }^{5}$ Although the use of induced hypotension during this operation is not widespread it has been a standard procedure for many years at Hjørring Municipal Hospital. Ten patients were ASA physical status class I, and one patient was in class II (mild bronchial asthma treated with theophyline and psychomotor epilepsy treated with carbamazepine). Resting MAP in the awake state averaged $93 \mathrm{mmHg}$ range (85-107).

\section{Anaesthesia}

The patients were premedicated with morphine $10-15 \mathrm{mg}$ IM and scopolamine $0.4-0.6 \mathrm{mg}$ IM depending on age and weight. One hour before induction af anaesthesia captopril $1 \mathrm{mg} \cdot \mathrm{kg}^{-1}$ PO was given. Induction of anaesthesia was with thiopentone $5-9 \mathrm{mg} \cdot \mathrm{kg}^{-1}$ IV followed by d-tubocurarine $0.5-0.9 \mathrm{mg} \cdot \mathrm{kg}^{-1}$ IV to facilitate tracheal intubation. Anaesthesia was maintained with enflurane $0.2-1.5$ per cent and nitrous oxide 60-75 per cent in oxygen. The patients' lungs were ventilated using intermittent positive pressure ventilation and a nonrebreathing system (AGA ventilator UV 705). Controlled hypotension was induced with a 0.01 per cent solution of SNP. The rate of infusion was regulated by an Ivac 531 infusion pump to maintain a MAP of $50 \mathrm{mmHg}$. 
TABLE I Mean arterial pressure (MAP), heart rate (HR) and cerebral vascular resistance (CVR) before, during and after hypotension induced with sodium nitroprusside in patients pretreated with captopril

\begin{tabular}{|c|c|c|c|c|c|c|c|c|c|}
\hline \multirow[b]{2}{*}{ Case no. } & \multicolumn{3}{|l|}{$\begin{array}{l}M A P \\
\left(m m H_{g}\right)\end{array}$} & \multicolumn{3}{|c|}{$\begin{array}{l}\text { HR } \\
\left(\text { beats } \cdot \mathrm{min}^{-1}\right)\end{array}$} & \multicolumn{3}{|c|}{$\begin{array}{l}C V R \\
\left(m m H g \cdot m l^{-1} \cdot 100 g^{-1} \cdot m i n^{-1}\right)\end{array}$} \\
\hline & Before & During & After & Before & During & After & Before & During & After \\
\hline 1 & 77 & 43 & 77 & 55 & 60 & 60 & 2.06 & 1.20 & 2.19 \\
\hline 2 & 53 & 44 & 72 & 62 & 63 & 52 & 1.76 & 4.23 & 4.29 \\
\hline 3 & 54 & 45 & 60 & 52 & 56 & 60 & 1.69 & 1.52 & 1.53 \\
\hline 4 & 60 & 45 & 63 & 54 & 66 & 58 & 1.32 & 0.82 & 1.10 \\
\hline 5 & 55 & 46 & 77 & 75 & 86 & 79 & 0.77 & 0.66 & 1.04 \\
\hline 6 & 54 & 44 & 65 & 78 & 73 & 70 & 1.21 & 0.98 & 1.33 \\
\hline 7 & 80 & 48 & 95 & 57 & 101 & 66 & 1.55 & 0.97 & 1.87 \\
\hline 8 & 63 & 54 & 89 & 83 & 72 & 63 & 1.01 & 1.06 & 1.50 \\
\hline 9 & 64 & 42 & 74 & 87 & 87 & 66 & 0.99 & 0.66 & 1.07 \\
\hline 10 & 57 & 46 & 75 & 75 & 68 & 70 & 1.38 & 1.60 & 1.82 \\
\hline 11 & 60 & 47 & 74 & 62 & 100 & 68 & 2.07 & 0.73 & 1.29 \\
\hline MEAN & 62 & 46 & 75 & 67 & 76 & 65 & 1.44 & 1.31 & 1.73 \\
\hline Paired & $b / d$ & $P<0.001$ & & $b / d$ & NS & & $\mathrm{b} / \mathrm{d}$ & NS & \\
\hline \multirow[t]{2}{*}{$t$ test } & $\mathrm{d} / \mathrm{a}$ & $P<0.001$ & & $d / a$ & $P<0.05$ & & $d / a$ & $P<0.01$ & \\
\hline & $b / a$ & $P<0.001$ & & $\mathrm{~b} / \mathrm{a}$ & NS & & $\mathrm{b} / \mathrm{a}$ & NS & \\
\hline
\end{tabular}

$b=$ before, $d=$ during, $a=$ after, NS $=$ non-significant.

\section{Monitoring and measurements}

Radial artery cannulation was performed and the arterial pressure was measured continuously with a pressure transducer (AME, $\mathrm{AE} 840$ ) connected to a diascope (S\&W 2), A catheter was inserted, by means of the Seldinger technique, into the right jugular venous bulb through the internal jugular vein. The ECG was monitored with the diascope (S\&W 2). Expired carbon dioxide concentrations were monitored continuously with a Capnograph Godart Mark 2. Blood gases were analysed intermittently on an ABL 3 Radiometer. The CBF was measured after an intravenous injection of 133 xenon into an arm vein. ${ }^{6}$ For each flow measurement $8.9-16.2 \mathrm{mCi}$ (330-600 MBq) 122 xenon dissolved in $0.8-1.7 \mathrm{ml}$ saline 0.9 per cent were used. The radiation emitted was detected by a Novo Cerebrograph $10 \mathrm{~A}$ with ten scintillation detectors, five over each hemisphere. Recording of the remaining activity in the brain was continued for 11 min, allowing the decay curve to be analysed into grey and white matter flow components by curve stripping techniques. ${ }^{7}$ The CBF was measured (1) 30 minutes after general anaesthesia had been established, (2) during stable induced hypotension, and (3) 15 minutes after cessation of the SNP infusion. No surgery was performed during measurements. At the beginning of each CBF determination, arterial and jugular venous blood samples were drawn for measurement of oxygen tension, carbon dioxide tension and haemoglobin concentration.

\section{Derived indices}

The CBF was based on the initial slope index (ISI) using the Ml calculation model. ${ }^{6-9}$ The CBF values were corrected assuming a four per cent change $\cdot \mathrm{mmHg}^{-1}$ difference in carbon dioxide tension. ${ }^{10}$ Cerebrovascular resistance (CVR) was calculated as $\mathrm{MAP} \cdot \mathrm{CBF}^{-1}$. Cerebral metabolic rate of oxygen $\left(\mathrm{CMRO}_{2}\right)$ for the brain, expressed as mmol $\mathrm{O}_{2} \cdot 100 \mathrm{~g}^{-1} \cdot \mathrm{min}^{-1}$, was derived as the product of CBF (uncorrected values) and the arteriojugular venous oxygen content difference. Values for $\mathrm{CBF}, \mathrm{CBF}_{\text {corr }}, \mathrm{MAP}, \mathrm{CVR}, \mathrm{A}-\mathrm{VO}_{2}, \mathrm{CMRO}_{2}, \mathrm{HR}, \mathrm{PaCO}_{2}$ were statistically analysed with a paired $t$ test.

\section{Results}

The combination of SNP and captopril decreased MAP from 62 to $46 \mathrm{mmHg}$, a 26 per cent decrease in MAP. After the cessation of SNP infusion there was an increase in MAP to an average of $75 \mathrm{mmHg}$ (Table I). The SNP dose ranged between 0.16 and $3.23 \mu \mathrm{g} \cdot \mathrm{kg}^{-1} \mathrm{~min}^{-1}$ (Table II). The duration of SNP infusion averaged 110 (70-232) minutes. Heart rate (HR) remained unchanged during hypotension. After hypotension, HR was significantly lower than during hypotension (Table I). The CBF and $\mathrm{CBF}_{\text {corr }}$ remained unchanged during hypotension. The CBF after hypotension was significantly higher than during hypotension. In contrast $\mathrm{CBF}_{\text {corr }}$ was significantly higher after hypotension compared with the value before hypotension (Table III). The CVR remained unchanged during hypotension. After hypotension, a significant increase was noticed when compared with the value during hypotension. There were no significant changes in A-V $\mathrm{O}_{2}$ and $\mathrm{CMRO}_{2}$ before, during and after hypotension. The observed low $\mathrm{A}-\mathrm{V} \mathrm{O}_{2}$ differences in patients one and ten might indicate retrograde flow in the internal jugular vein during blood sampling. In patient number two low CBF 
TABLE II Doses of sodium nitroprusside (SNP) used for induced hypotension in 11 patients pretreated with captopril

\begin{tabular}{lll}
\hline Case no. & $\begin{array}{l}\text { SNP-dose } \\
\left(\mathrm{mg} \cdot \mathrm{kg}^{-1}\right)\end{array}$ & $\begin{array}{l}\text { SNP-dose } \\
\left(\mu \mathrm{g} \cdot \mathrm{kg}^{-1} \cdot \mathrm{min}^{-1}\right)\end{array}$ \\
\hline 1 & 0.26 & 2.56 \\
2 & 0.11 & 0.84 \\
3 & 0.03 & 0.31 \\
4 & 0.05 & 0.61 \\
5 & 0.08 & 1.14 \\
6 & 0.01 & 0.16 \\
7 & 0.23 & 3.23 \\
8 & 0.20 & 1.30 \\
9 & 0.58 & 2.50 \\
10 & 0.03 & 0.23 \\
11 & 0.18 & 2.21 \\
Mean & 0.16 & 1.37 \\
\hline
\end{tabular}

and $\mathrm{CBF}_{\text {corr }}$ values were recorded during and after hypotension. This patient had low $\mathrm{CMRO}_{2}$ values. In patients one and ten low A-V $\mathrm{O}_{2}$ and $\mathrm{CMRO}_{2}$ values were noted (Table III). The injection of d-tubocurarine did not provoke any decrease in blood pressure.

\section{Discussion}

Autoregulation maintains CBF constant despite wide variations in cerebral perfusion pressure. Autoregulation predominates the control of the cerebral circulation under normal physiological conditions. In addition CBF is controlled through metabolic regulation, chemical and neurogenic control. ${ }^{1}{ }^{10}$ Sodium nitroprusside (SNP) is commonly used to produce hypotension. The drug dilates cerebral vessels and might preserve $\mathrm{CBF}$ during hypotension. This assumption is supported by studies carried out on patients undergoing operation for cerebral aneurysms during general anaesthesia. ${ }^{11-13}$ On the contrary, in studies performed in the awake state a decrease in CBF during SNP hypotension was observed. An increased sympathetic activity constricting the larger intracranial vessels might explain this. ${ }^{14-15}$ This sympathetic activity is suppressed by general anaesthesia. The usefulness of SNP is limited by the risk of cyanide toxicity in situations with high-dose requirements.

Increased activity of the renin-angiotensin system is partially responsible for the resistance to SNP. Captopril inhibits angiotensin converting enzyme to block the cardiovascular effects of the renin-angiotensin system. ${ }^{4}$ As a consequence, captopril potentiates the hypotensive effect of SNP and the SNP dose requirement is reduced. ${ }^{2-4}$

Several studies in rats have shown that CBF during captopril induced hypotension (lower MAP limit 30-40 $\mathrm{mmHg}$ ) is preserved. Both the upper and lower limits of autoregulation were reset to lower mean arterial pressures. This mechanism may be ascribed to diminished action of angiotensin II on the cerebral blood vessels..$^{16-19}$ In our investigation the patients were anaesthetized with thiopentone, nitrous oxide and enflurane. These drugs influence the level of $\mathrm{CBF}$ and $\mathrm{CMRO}_{2}$. Thiopentone causes a parallel reduction of $\mathrm{CMRO}_{2}$ and $\mathrm{CBF},{ }^{10}$ but in

TABLE II] Cerebral blood flow (CBF), CBF corrected for changes in arterial partial pressure of carbon dioxide $\left(\mathrm{PaCO}_{2}\right)$, arteriovenous oxygen content differences $\left(\mathrm{A}-\mathrm{V} \mathrm{O} \mathrm{O}_{2}\right)$ and calculated metabolic rate of oxygen $\left(\mathrm{CMRO}_{2}\right)$ before, during and after hypotension induced with sodium nitroprusside in patients pretreated with captopril

\begin{tabular}{|c|c|c|c|c|c|c|c|c|c|c|c|c|c|c|c|}
\hline \multirow[b]{3}{*}{ Case no. } & \multicolumn{3}{|l|}{$C B F$} & \multicolumn{3}{|c|}{$C B F$ corr. } & \multicolumn{3}{|c|}{$\mathrm{PaCO}_{2}$} & \multicolumn{3}{|c|}{$\mathrm{A} \cdot \mathrm{VO}_{2}$} & \multicolumn{3}{|c|}{$\mathrm{CMRO}_{2}$} \\
\hline & \multicolumn{3}{|c|}{$\left(\mathrm{ml} \cdot 100 \mathrm{~g}^{-1} \cdot \mathrm{min}^{-1}\right)$} & \multicolumn{3}{|c|}{$\left(m / \cdot 100 g^{-1} \cdot \min ^{-1}\right)$} & \multicolumn{3}{|c|}{$(k P a)$} & \multicolumn{3}{|c|}{$\left(\mathrm{mmol} \mathrm{O}_{2} \cdot 100 \mathrm{ml}^{-1}\right)$} & \multicolumn{3}{|c|}{$\left(\mathrm{mmol} \mathrm{O}_{2} \cdot 100 \mathrm{~g}^{-1} \cdot \mathrm{min}^{-1}\right)$} \\
\hline & $b$ & $d$ & $a$ & $b$ & $d$ & $a$ & $b$ & $d$ & $a$ & $b$ & $d$ & $a$ & $b$ & $d$ & $a$ \\
\hline I & 37.4 & 35.9 & 35.1 & 41.8 & 41.6 & 40.5 & 4.91 & 4.77 & 4.79 & 0.03 & 0.03 & 0.10 & 0.01 & 0.01 & 0.03 \\
\hline 2 & 30.1 & 10.4 & 16.8 & 24.3 & 10.2 & 17.5 & 5.94 & 5.37 & 5.16 & 0.20 & 0.30 & 0.27 & 0.06 & 0.03 & 0.04 \\
\hline 3 & 31.9 & 29.6 & 39.1 & 39.2 & 40.1 & 50.5 & 4.54 & 4.12 & 4.33 & 0.35 & 0.37 & 0.31 & 0.11 & 0.11 & 0.12 \\
\hline 4 & 45.6 & 55.0 & 59.1 & 44.6 & 45.9 & 48.6 & 5.37 & 5.85 & 5.89 & 0.29 & 0.24 & 0.21 & 0.13 & 0.13 & 0.12 \\
\hline 5 & 71.7 & 70.7 & 73.1 & 61.5 & 67.9 & 66.1 & 5.77 & 5.40 & 5.64 & 0.13 & 0.16 & 0.12 & 0.10 & 0.11 & 0.09 \\
\hline 6 & 44.4 & 44.8 & 48.8 & 25.4 & 40.1 & 48.2 & 6.72 & 5.65 & 5.34 & 0.19 & 0.23 & 0.21 & 0.09 & 0.10 & 0.10 \\
\hline 7 & 51.6 & 49.6 & 50.7 & 38.1 & 53.9 & 46.9 & 6.17 & 5.01 & 5.55 & 0.20 & 0.22 & 0.20 & 0.10 & 0.11 & 0.10 \\
\hline 8 & 62.4 & 50.8 & 59.1 & 41.9 & 41.8 & 56.2 & 6.39 & 5.89 & 5.46 & 0.23 & 0.27 & 0.20 & 0.15 & 0.13 & 0.12 \\
\hline 9 & 64.4 & 63.4 & 69.1 & 39.1 & 44.7 & 63.5 & 6.65 & 6.28 & 5.57 & 0.15 & 0.15 & 0.12 & 0.10 & 0.09 & 0.08 \\
\hline 10 & 41.3 & 28.8 & 41.1 & 38.4 & 28.8 & 39.0 & 5.53 & 5.30 & 5.47 & 0.06 & 0.22 & 0.16 & 0.02 & 0.06 & 0.09 \\
\hline 11 & 29.0 & 64.6 & 57.5 & 32.4 & 54.3 & 50.9 & 4.91 & 5.83 & 5.68 & 0.25 & 0.15 & 0.16 & 0.07 & 0.10 & 0.09 \\
\hline Mean & 46.3 & 45.7 & 50.0 & 38.8 & 42.7 & 48.0 & 5.71 & 5.41 & 5.35 & 0.19 & 0.21 & 0.19 & 0.09 & 0.09 & 0.09 \\
\hline & $b / d$ & \multirow{3}{*}{\multicolumn{2}{|c|}{$\begin{array}{l}\text { NS } \\
P<0.05 \\
\text { NS }\end{array}$}} & $b / d$ & \multicolumn{2}{|l|}{ NS } & $\mathrm{b} / \mathrm{d}$ & NS & & $\mathrm{b} / \mathrm{d}$ & \multicolumn{2}{|l|}{ NS } & $b / d$ & \multicolumn{2}{|l|}{ NS } \\
\hline \multirow{2}{*}{ t test } & $d / a$ & & & $d / a$ & NS & & $d / a$ & NS & & $\mathrm{d} / \mathrm{a}$ & NS & & $d / a$ & NS & \\
\hline & $b / a$ & & & $\mathbf{b} / \mathbf{a}$ & \multicolumn{2}{|c|}{$P<0.05$} & $\mathrm{~b} / \mathrm{a}$ & NS & & $\mathrm{b} / \mathrm{a}$ & NS & & b/a & NS & \\
\hline
\end{tabular}

$b=$ before, $d=$ during, $a=$ after, $N S=$ non-significant 
this study the effect was minimal at the time of the first measurement, $45 \mathrm{~min}$ after induction of anaesthesia. Enflurane is a cerebral vasodilator and suppresses $\mathrm{CMRO}_{2-}{ }^{10}$ Nitrous oxide causes a decrease in $\mathrm{CMRO}_{2}$, but has minimal effect on CBF. ${ }^{1}$ Thus the exact critical ischaemic threshold of CBF is unknown. Most authors quote a level of about $20 \mathrm{ml} \cdot 100 \mathrm{~g}^{-1} \cdot \mathrm{min}^{-1}$ in lightly anaesthesized man, below which the electroencephalogram gradually disappears ${ }^{10,}{ }^{20}$ In this study no control group was studied without captopril pretreatment. Thus, we can only compare hypotensive values with pre-hypotensive values. In the group as a whole CBF remained unchanged during hypotension. Concerning the CBF values corrected for deviations in $\mathrm{PCO}_{2}$ it must be emphasized that the size of the correction factor (four per cent) is debatable. In particular, during SNP-induced hypotension the factor is probably smaller because cerebral vessels show reduced sensitivity to $\mathrm{PCO}_{2}$ changes. ${ }^{2 \mathrm{I}}$

In one patient, number two, critical low $\mathrm{CBF}$ and $\mathrm{CBF}_{\text {corr }}$ values were recorded during and after hypotension (Table III). Values of CBF below $25 \mathrm{ml} \cdot 100$ $\mathrm{g}^{-1} \cdot \mathrm{min}^{-1}$ are subject to methodological uncertainties, because of the relatively large "contamination" from extracranial bloodflow when using IV method, thus these low values can be interpretated as just less than $25 \mathrm{ml} \cdot 100$ $\mathrm{g}^{-1} \cdot \min ^{-1}$. In patient number two an increase in the $\mathrm{A}-\mathrm{V}$ $\mathrm{O}_{2}$ values during and after hypotension was noticed. This may indicate larger $\mathrm{O}_{2}$ extraction induced by the decrease in CBF (Table III). The patient had no neurological deficit postoperatively.

In our study it was possible to obtain the desired level of blood pressure using very small doses of SNP which were well below the recommended maximum dose of about $1 \mathrm{mg} \cdot \mathrm{kg}^{-1}$ or $10 \mu \mathrm{g} \cdot \mathrm{kg}^{-1} \cdot \mathrm{min}^{-122}$ (Table II). Some of the patients $(1,4,7,8,9,11)$ had relatively high initial MAP values ( $\geqslant 60 \mathrm{mmHg}$ ) and received the largest SNP doses (mean $2.07 \mu \mathrm{g} \cdot \mathrm{kg}^{-1} \cdot \mathrm{min}^{-1}$. On the contrary, in the rest of the patients, the combination of captopril and anaesthesia alone resulted in low MAP values ( $\leqslant$ $60 \mathrm{mmHg}$ ). As a consequence they received the lowest doses of SNP (mean $0.54 \mu \mathrm{g} \cdot \mathrm{kg}^{-1} \cdot \min ^{-1}$ ). These patients also were more sensitive to the vasodilating effect of enfluraine which might explain the occasional low dose ( 0.2 per cent) used. The low SNP doses may constitute a risk because the patients do not receive the beneficial dilating effect of SNP on the cerebral vessels, which might preserve CBF during hypotension.

In conclusion, we found that the desired level of hypotension was obtained in this group of young patients using nontoxic doses of SNP combined with captopril. In the group as a whole there were no changes in $\mathrm{CBF}$ and $\mathrm{CMRO}_{2}$ during hypotension, but the critical low CBF measurements recorded in one of our patients indicate the need for further studies to evaluate the cerebral haemodynamic consequences of captopril and SNP induced hypotension.

\section{Acknowledgements}

We thank Drs. S. Elb and H. Hansen for their advice and help and E. Folkmar for secretary assistance. The study was supported by the Niels Jensen Foundation.

\section{References}

$1 \mathrm{MCDowall} D \mathrm{G}$. Induced hypotension and brain ischaemia. Br J Anaesth 1985; 57: 110-9.

2 Jennings GL, Gelman JS, Stockigt JR, Korner PI. Accentuated hypotensive effect of sodium nitroprusside in man after captopril. Clin Sci 1981; 61: 521-6.

3 Fahmy NR. Impact of oral captopril or propanolol on nitroprusside-induced hypertension. Anesthesiology 1984; 61: A41.

4 Woodside J, Garner L, BedfordRF et al. Captopril reduces the dose requirement for sodium nitroprusside induced hypotension. Anesthesiology 1984; 60: 413-7.

5 Cortle MH, Loring RM, Fischer GG, Gaynon IE. The "Maxilla-Premaxilla" approach to extensive nasal septum surgery. Arch Otolaryngol 1958; 60: 301-13.

6 Obrist WS, Wilkinson WE. Stability and sensitivity of CBF indices in the noninvasive ${ }^{133} \mathrm{Xe}$ method. In: Cerebral Blood Flow and Metabolism Measurement. Hartmann A, Hoyer S (Eds.). Berlin Heidelberg: Springer-Verlag, 1985: 30-6.

7 Lassen NA. Kinetic and compartmental analysis of inert gas clearance curves for measurement of blood flow. $I n$ : Blood Flow through Organs and Tissues. Edinburgh: Livingstone, 1968: 210-4.

8 Obrist WD, Wang HS. Comparison of 133-xenon inhalation and iv-injection in regional CBF studies. In: Cerebral Vascular Disease 3, Excerpta Medica, Elsevier 1980: 140-4.

9 Risberg $J$ et al. Regional Cerebral Flow by 133-xenon inhalation. Stroke 1975; 6: 142-8.

10 Lassen NA, Christensen MS. Physiology of cerebral blood flow. Br J Anaesth 1976; 48: 719-34.

11 Griffiths DPG, Cummins BH, Greenbaum R et al. Cerebral blood flow and metabolism during hypotension induced with sodium nitroprusside. Br J Anaesth 1974; 46: 671-9.

12 Henriksen $L$, Thorshauge C, Harmsen A et al. Controlled hypotension with sodium nitroprusside: effects on cerebral blood flow and cerebral venous blood gases in patients operated for cerebral aneurysms. Acta Anaesthesiol Scand $1983 ; 27 ; 62-7$.

13 Larsen $R$, Teichmann J, Hilfiker $O$ et al. Nitroprussidehypotension: cerebral blood flow and cerebral oxygen consumption in neurosurgical patients. Acta Anaesthesiol Scand 1982; 26: 327-30. 
14 Henriksen L, Paulson OB, Lauritzen $M$. The effects of sodium nitroprusside on cerebral blood flow and cerebral venous blood gases. 1. Observations in awake man during and following moderate blood pressure reduction. Eur J Clin Invest 1982; 12: 383-7.

15 Henriksen $L$, Paulson $O B$. The effects of sodium nitroprusside on cerebral blood flow and cerebral venous blood gases. 2. Observations in awake man during succesive blood pressure reduction. Eur J Clin Invest 1982; 12: 389-93.

16 Jarden JO, Barry DI, Strandgaard S et al. Cerebrovascular effect of the converting enzyme inhibitor captopril. J Hypertens 1983; 2: 126-8.

17 Barry DI, Paulson OB, Jarden JO ef al. Effects of captopril on cerebral blood flow in normotensive and hypertensive rats. Am J Med 1984; 31: 79-85.

18 Barry DI, Jarden JO, Paulson OB et al. Cerebrovascular aspects of converting-enzyme inhibition I: Effects of intravenous captopril in spontaneously hypertensive and normotensive rats. J Hypertens 1984; 2: 589-97.

19 Strandgaard S, Barry DI, Paulson OB. Converting enzyme inhibition and autoregulation of cerebral blood flow in spontaneously hypertensive and normotensive rats. Scand J Urol Nephrol (Suppl) 1984; 79: 35-8.

20 Heiss WD. Flow thresholds of functional and morphological damage of brain tissue. Stroke 1983; 14: 329-31.

21 Gregory $P$, Ishikawa $T, M C$ Dowall $D G . \mathrm{CO}_{2}$ responses of the cerebral circulation during drug-induced hypotension in the cat. J Cereb Blood Flow Metab 1981; 1: 195-201.

22 Christensen $K N$, Stokke SB, Andersen PK et al. Natriumnitroprussid og det kliniskc anvendelse. Ugeskr Lacger 1978; 140: 1411-4.
Résumé

Nous présentons les mesures des métabolisme et flot sanguin cérébraux $\left(\mathrm{CMRO}_{2}\right.$ et $\left.\mathrm{CBF}\right)$ de 11 patients sous anesthésie générale et hypotension controlée par nitroprussiate de sodium et captopril. Pour le flot, nous avons utilise un Novo Cerebrograph $10 \mathrm{~A}$, après injection intraveineuse de ${ }^{133}$ xenon tandis que le métabolisme était calculé à partir d'échantillons sanguins veineux et artériels. Les patients prenaient le captopril à la dose de $1 \mathrm{mg} \cdot \mathrm{kg}^{-1} \mathrm{PO}$ une heure avant l'induction de l'anesthésie et ils ont requis des doses de nitroprussiate allant de 0.16 a $3.23 \mu \mathrm{g} \cdot \mathrm{kg}^{-1} \cdot \mathrm{min}^{-1}$ pour abaisser leur pression artérielle moyenne de 26 pour cent jusqu' a $46 \mathrm{mmHg}$ pendant la période d' hypotension controlée. Nous n' avons pas pu identifier pour l' ensemble du groupe de modification significative du $C B F$ ou du $\mathrm{CMRO}_{2}$ avec l'hypotension, quoique dans un cas, le CBF était très faible pendant et après cette période. L'impact de l'hypotension au captopril et nitroprussiate sur l'hémodynamie cérébrale mérite donc une étude plus poussée. 